\title{
Tenderness of Beef as Measured by the Warner-Bratzler Shears
}

\author{
Ismael Carlo, E. Prieto, R. Mendoza, and C. L. Arcelay ${ }^{1}$
}

\section{INTRODUCTION}

The total amount of quality beef produced in Puerto Rico is an important consumer factor. Tenderness is a useful measure of beef quality. This paper reports on tenderness determinations conducted as part of a study on carcass characteristics of 18-month-old dairy-beef bulls.

\section{MATERIALS AND METHODS}

The tenderness of the top rounds and the rib roasts from the 9th, 10th, and 11th rib area from 102 crossbred bulls was evaluated by the WarnerBratzler shears.

The bulls, crossbreds of Brahman, Charolaise or Angus breed bulls and cull dairy cows, exclusively pasture-fed, were slaughtered at 18 months of age.

Each animal was slaughtered after a 24-hour preslaughter fasting period. The carcasses were cut after refrigeration for 24 hours at an average temperature of $35^{\circ} \mathrm{F}$. The rounds and rib roasts were then wrapped and packaged in cellophane bags, and kept in a freezer for approximately 1 month.

The top rounds were thawed at about $32^{\circ} \mathrm{F}$. for 48 hours and the rib roasts for 72 hours. All were weighed before cooking. The round roasts were cooked uncovered to an internal temperature of $170^{\circ} \mathrm{F}$. in an oven at $325^{\circ} \mathrm{F}$; t the rib roasts were cooked, covered with aluminum foil, to an internal temperature of $160^{\circ} \mathrm{F}$. in an oven at $325^{\circ} \mathrm{F}$. Each roast was measured and weighed when its internal temperature dropped to $150^{\circ} \mathrm{F}$.

Cores of about $1 / 2$ inch in diameter and 1 inch long were used for the Warner Bratzler measurements. Three cores were sheared from each sample roast and the average taken as the tenderness of its beef. The number of pounds of shearing stress needed in each measurement indicates the degree of tenderness; the fewer the pounds required obviously indicates the most tender.

1 Animal Husbandman and Professor, Assistant Animal Husbandman, Associate Agronomist, and Professor and Animal Husbandman, respectively, Agricultural Experiment Station and College of Agriculture and Mechanical Arts, Mayagüez Campus, University of Puerto Rico, Mayagiez and Rio Piedras, P.R. 


\section{RESULTS AND DISCUSSION}

The average tenderness, expressed in pounds of shearing stress for top rounds and rib roasts of the several crosses, is shown in table 1.

The comparison of average tenderness for the top rounds indicated a significant difference among the crosses compared. The Duncan Multiple Test ${ }^{2}$ showed no significant difference in tenderness between the Charolaise and the Angus, but that both were significantly superior to the Brahman crossbred bulls. In other words, the Angus and the Charolaise crossbreds had about the same tenderness, while the Brahman crossbreds showed a harder meat.

The comparison of the average tenderness for the rib roasts indicated a significant difference among the three crosses. The Duncan Multiple Test showed no significant difference between the Charolaise and the Brahman

TABLE 1.-Average tenderness of top round and rib roast cuts of the different crosses

\begin{tabular}{l|c|c|c}
\hline \multirow{2}{*}{ Cross } & \multirow{3}{*}{ Number of animals } & \multicolumn{2}{|c}{$\begin{array}{c}\text { Average tenderness expressed as pounds of } \\
\text { sheer stress }\end{array}$} \\
\cline { 2 - 4 } & & Top round & Rib roast \\
\hline Brahman & 35 & $7.52 \mathrm{a}^{\mathrm{l}}$ & $12.91 \mathrm{a}$ \\
Charolaise & 41 & $6.44 \mathrm{~b}$ & $13.01 \mathrm{a}$ \\
Angus & 26 & $6.32 \mathrm{~b}$ & $11.25 \mathrm{~b}$ \\
\hline
\end{tabular}

1 Means followed by the same letter do not differ significantly at 5-percent level.

crossbreds, while the Angus crossbreds were significantly more tender than either.

In both comparisons, the Angus had the tenderest meat of the three crosses, even though the comparison of the top rounds showed no statistically significant difference between it and the Charolaise. The average figures showed a tendency to more tenderness of meat in the Angus crossbreds.

A comparison of the rib roasts to the top rounds in the Angus crossbreds (table 2) showed a highly significant difference between these two cuts of beef. The rib roasts were clearly and definitively harder than the top rounds. No significant difference was found between animals compared. Since the Angus crosses had the least difference in tenderness between these two cuts, the results must also hold true for the Brahman and the Charolaise crossbreds. For this reason, no statistical analysis was performed in these two crosses.

Steel, R. G. D., and Torrie, J. H., Principles and Procedures of Statistics, MeGraw-Hill Book Co., N.Y., 1960: 


\section{SUMMARY}

A total of 102 dairy-beef bulls were slaughtered at 18 months of age, and the tenderness of their beef determined by the Warner-Bratzler shear method. The bulls were crossbreds of Brahman, Charolaise or Angus bulls and cull dairy cows.

The comparisons indicated that the Angus crossbreds were significantly more tender in the rib roasts than the two other crosses. No significant difference was found in the tenderness of the top rounds between this cross and the Charolaise. Both had a more tender top round than the Brahman crossbreds. The Angus crossbreds had a lower average, or more tenderness, than the Charolaise.

A highly significant difference was shown to exist between the rib roasts

TaBLe 2.-Analysis of variance for average tenderness of top round vs. rib roast cuts in the Angus cross

\begin{tabular}{l|c|c|c|c}
\hline Source of variation & D/F & SS & M.S. & F \\
\hline Cuts & 1 & 316.20 & 316.20 & $49.40^{2}$ \\
Animals & 25 & 215.85 & 8.63 & $1.35 \mathrm{NS}$ \\
Exror & 25 & 160.20 & 6.40 & \\
\hline Total & 51 & 692.25 & & \\
\hline
\end{tabular}

${ }^{1}$ Significant at 1-percent level.

and the top rounds, definitely establishing that top round cuts were more tender than rib roast cuts.

\section{RESUMEN}

Se sacrificaron 102 toros de 18 meses de edad, y se determinó la blandura de su carne mediante el método Warner-Bratzler. Estos animales representaban cruces entre toros Brahman, Charolesa o Angus y vacas lecheras desechadas.

Las comparaciones demostraron que los asados de costilla de los cruces con Angus eran más blandos que los de los otros dos cruces. No hubo diferencia significativa en cuanto a la blandura de la "gallina" 3 entre los animales del cruce con Angus y los de cruce con Charolesa, aunque el promedio de la medida de blandura favoreció a los primeros.

Se demostró definitivamente en todos los cruces comparados que la "gallina" es más tierna que el asado de costilla.

s Este término se utiliza corrientemente en Puerto Rico para denominar el músculo de mayor tamaño del muslo trasero. 